\title{
PENGARUH METODE THINK, PAIR AND SHARE TERHADAP KETERAMPILAN KADER DALAM PENGISIAN KMS BALITA
}

\author{
"Intan Gumilang Pratiwi ${ }^{1}$ dan Dian Aby Restanty ${ }^{2}$ \\ ${ }^{1}$ Poltekkes Kemenkes Mataram \\ ${ }^{2}$ Poltekkes Kemenkes Malang \\ *intangumil@gmail.com)
}

Diterima : 14 Januari 2019 Direvisi : 15 Januari 2019 Disetujui: 17 Januari 2019

\begin{abstract}
ABSTRAK
Salah satu sasaran Sustainanable Development goals yang tertuang dalam rencana pembangunan jangka menengah tahun 2030 adalah menurunkan angka kematian ibu dan bayi. Untuk mencapai tujuan tersebut maka salah satunya melalui pengembangan wahana peran serta masyarakat melalui pelaksanaan pembangunan masyarakat desa dalam bentuk Posyandu. Posyandu merupakan tempat untuk memberikan pelayanan dasar kesehatan ibu dan anak yang dikelola kader kesehatan. Tugas kader salah satunya adalah melakukan penimbangan balita dan melakukan pencatatan dalam kartu menuju sehat (KMS).Penelitian ini bertujuan menganalisis pengaruh metode think, pair and share terhadap keterampilan kader dalam pengisian KMS. Desain yang digunakan dalam penelitian ini adalah desain penelitian preexperimental design

menggunakan pendekatan One-Group Pretest-Posttest Designjumlah sampel 25 kader.Data dianalisis dengan paired t-test. Hasil penelitian ini adalah ada pengaruh metode pembelajaran think, pair and share dalam meningkatkan keterampilan kader mengisi KMS dengan nilai $\mathrm{P}$ $<0,01$.
\end{abstract}

Kata Kunci:Think Pair and Share, Keterampilan, Kader, KMS

\section{ABSTRACT \\ THE EFFECT OF THINK, PAIR AND SHARE METHODS ON THE SKILLS OF CADRES IN FILLING IN KMS.}

One of the Sustainanable Development goals set out in the mid-term development plan of 2030 is to reduce maternal and infant mortality. To achieve this goal, one of them is through the development of a vehicle for community participation through the implementation of village community development in the form of a Posyandu. Posyandu is a place to provide basic services for maternal and child health managed by health cadres. One of the cadres' tasks is to weigh toddlers and make notes on a health-headed card (KMS). This study aims to analyze the effect of think, pair and share methods on the skills of cadres in filling in KMS. The design used in this study was a pre-experimental design designusing the One-Group Pretest-Posttest Design approach with a sample of 25 cadres. Data were analyzed by paired ttest. The results of this study are the influence of think, pair and share learning methods in improving the skills of cadres in filling out KMS with a value of $\mathrm{P}<0.01$.

Key Words: Think, Pair And Share, Skills Of Cadres, KMS 


\section{Pendahuluan}

\section{Salah satu sasaran sustainabledevelopment goals yang} tertuang dalam rencana pembangunan jangka menengah tahun 2030 adalah menurunkan angka kematian ibu dan bayi.Untuk mencapai tujuan tersebut maka salah satunya melalui pengembangan wahana peran serta masyarakat melalui pelaksanaan pembangunan masyarakat desa dalam bentuk Posyandu.Posyandu merupakan tempat untuk memberikan pelayanan dasar kesehatan ibu dan anak yang dikelola kader kesehatan. Tugas kader salah satunya adalah melakukan penimbangan balita dan melakukan pencatatan dalam kartu menuju sehat (KMS). Dalam melakukan pencatatan KMS, kader mendapatkan pelatihan dari tenaga kesehatan yang bertanggung jawab di posyandu.Dalam kegiatan pelatihan tersebut kader diupayakan secara optimal sehingga terampil dalam pengisian KMS.Oleh karena itu, mereka harus dibina, di tuntun, serta di dukung oleh pendidik yang terampil dan berpengalaman serta dengan metode pembelajaran yang menarik dan tidak membosankan.

Metode think, pair and share yaitu model pembelajaran yang memberi kesempatan pada peserta didik untuk berfikir, berdiskusi berpasangan dengan sesama teman dan berbagi ke seluruh teman. Di dalam metode tersebut memungkinkan peserta didik untuk berfikir secara mandiri, maupun kelompok sehingga dirasa tepat jika pembelajaran pengisian KMS disampaikan menggunakan metode ini.

Tujuan dari penelitian ini adalah untuk menganalisis pengaruh metode pembelajaran think, pair and share terhadap keterampilan kader dalam mengisi KMS.

\section{A. METODE THINK, PAIR AND SHARE}

Metode pembelajaran Think-Pair-

Share dikembangkan oleh Frank Lyman dkk dari Universitas Maryland pada tahun 1985. Metode pembelajaran Think-PairShare merupakan salah satu metode pembelajaran kooperatif sederhana.

Metode pembelajaran think,pair and share adalah metode pembelajaran yang memberi kesempatan pada peserta didik untuk berfikir kelompok dan secara individu. Pembelajaran diawali dengan pengajuan soal yang harus dipikirkan secara individu lalu berpasangan mendiskusikan hasil pemikiran, lalu berbagi kepada seluruh kelas apa yang didiskusikan.(Abdurrahman Usman, 2015; Abidin, Amin, \& Sulaiman, 2018; Bugis \& Buru, 2018; Marhaeni, Putra, \& Jaya, 2013; Raba, 2017; Yulianingsih et al., 2017)

Tahap utama dalam pembelajaran ThinkPair-Share adalah sebagai berikut.

Tahap 1: Thingking (berpikir) guru mengajukan pertanyaan atau isu yang berhubungan dengan pelajaran. Kemudian siswa diminta untuk memikirkan pertanyaan atau isu tersebut secara mandiri untuk beberapa saat.

Tahap 2 :Pairing(berpasangan) guru meminta siswa berpasangan dengan siswa lain untuk mendiskusikan apa yang telah dipikirkannya pada tahap pertama. Dalam tahap ini, setiap anggota pada kelompok membandingkan jawaban atau hasil pemikiran mereka dengan mendefinisikan jawaban yang dianggap paling benar. Biasanya guru memberi waktu 4-5 menit untuk berpasangan. Tahap 3 : Sharing (berbagi) Pada tahap sharing, guru meminta kepada pasangan untuk berbagi dengan seluruh kelas tentang apa yang telah mereka bicarakan.Keterampilan berbagi 
dalam seluruh kelas dapat dilakukan dengan menunjuk pasangan yang secara sukarela bersedia melaporkan hasil kerja kelompoknya atau bergiliran pasangan demi pasangan hingga sekitar beberapa pasangan telah mendapat kesempatan untuk melaporkan.(Bugis \& Buru, 2018)

Manfaat pembelajaran ini adalah siswa mampu mengembangkan kemampuan maupun keterampilan yang dimilikinya baik sendiri ataupun dengan pasangannya kemudian kemampuan/keterampilan tersebut diungkapkan dengan berbagi ke seluruh kelas. teknik belajar mengajar think pair share mempunyai beberapa keuntungan sebagai berikut:mudah dilaksanakan dalam kelas yang besar,memberikan waktu kepada siswa untuk merefleksikan isi materi pelajaran, memberikan waktu kepada siswa untuk melatih mengeluarkan pendapat sebelum berbagi dengan kelompok kecil atau kelas secara keseluruhan.

\section{B. KMS (Kartu Menuju Sehat)}

Kartu Menuju Sehat (KMS) adalah kartu yang memuat grafik pertumbuhan serta indikator perkembangan yang bermanfaat untuk mencatat dan memantau tumbuh kembang balita setiap bulan sejak lahir sampai usia 5 tahun. (Kementerian Kesehatan RI, 2010; Nursalam., Agustina, D., 2010)

KMS juga diartikan sebagai "rapor" kesehatan dan gizi.KMS digunakan untuk mencatat berat badan anak dan pemberian kapsul vitamin A serta menilai hasil penimbangan.Bila berat badan tidak naik 1 kali kader dapat memberikan penyuluhan tentang asuhan dan pemberian makanan anak. Bila tidak naik 2 kali atau berat badan berada di bawah garis merah kader perlu merujuk ke petugas kesehatan terdekat,agar anak mendapatkan pemeriksaan lebih lanjut.(Endo Dardjito, Colti Sistiarani, 2014)

KMS juga digunakan kader untuk memberikan pujian kepada ibu bila berat badan anaknya naik, serta mengingatkanibu untuk menimbangkan anaknya di posyandu pada bulan berikutnya.

Grafik pertumbuhan KMS dibuat berdasarkan baku WHO - NCHSyang disesuaikan dengan situasi Indonesia. Gambar grafik pertumbuhan dibagi dalam 5 blok sesuai dengan golongan umur balita. Setiap blok dibentuk oleh garis tegak / skala beratdalam $\mathrm{kg}$ dan garis datar skala umur menurut bulan. Blok 1 untuk bayi berumur $0-12$ bulan, blok 2 untuk anak golongan umur 13 - 24 bulan, blok 3 untuk anak golongan umur 25 - 36 bulan. Grafik pertumbuhan untuk bayi dan anak sampai dengan umur 36 bulan terdapat pada halaman dalam KMS.

Sedangkan untuk anak umur 37-60 bulan terdapat pada halaman berikutnya yang dibagi menjadi 2 blok yaitu blok ke 4 untuk anak umur $37-48$ bulan dan blok ke 5 untuk anak golongan yang umur 49 60 bulan. Dalam setiap blok, grafik pertumbuhan dibentuk dengan garis merah (agak melengkung) dan pita warna kuning, hijau dan hijau tua.

Langkah pengisian KMS adalah:

1. Memilih KMS sesuai jenis kelamin.

KMS berwarna biru untuk anak laki-laki dan KMS berwarna merah muda untuk anakperempuan.

2. Mengisi identitas anak dan orang tua pada halaman muka KMS.

Tuliskan identitas anak dan orang tua pada kolom pengisian data identitas.

3. Mengisi bulan lahir dan bulan penimbangan anak

Tulis bulan lahir anak pada kolom 0 (nol) bulan, tulis semua kolom bulan 
penimbangan berikutnya secara berurutan. Apabila anak tidak diketahui tanggalkelahirannya, tanyakan perkiraan umur anak tersebut. Tulis bulan saat penimbangan pada kolom sesuai umurnya.Tulis semua kolom bulan penimbangan berikutnya secara berurutan.

4. Meletakkan titik berat badan dan membuat garis pertumbuhan anak

Letakkan (plot) titik berat badan hasil penimbangan.Hubungkan titik berat badan bulan ini dengan bulan laluJika bulan sebelumnya anak ditimbang, hubungkan titik berat badan bulan lalu dengan bulan ini dalam bentuk garis lurus. Jika anak bulan lalu tidak ditimbang, maka garispertumbuhan tidak dapat dihubungkan

5. Mencatat setiap kejadian yang dialami anak

Catat setiap kejadian kesakitan yang dialami anak.Contohnya anak mengalami diare, tidak mau makan, demam.

6. Menentukan status pertumbuhan anak

Status pertumbuhan anak dapat diketahui dengan 2 cara yaitu dengan menilaigaris pertumbuhannya atau dengan menghitung kenaikan berat badan anak dibandingkan dengan kenaikan berat badan minimum (KBM). Kesimpulan dari penentuan status pertumbuhan adalah seperti tertera sebagai berikut: dikatakan naik apabila grafik $\mathrm{BB}$ (Berat Badan) mengikuti garis pertumbuhan atau kenaikan BB sama dengan KBM (kenaikan BB minimal) atau lebih. Dikatakan tidak naik apabila grafik BB mendatar atau menurun memotong garis pertumbuhan dibawahnya atau kenaikan BB kurang dari KBM (kenaikan BB minimal)
7. Mengisi catatan pemberian imunisasi bayi

Tanggal imunisasi diisi tiap kali setelah imunisasi diberikan

8. Mengisi catatan pemberian kapsul vitamin A

Tanggal diisi oleh kader sesuai dengan tanggal danbulanpemberian kapsul vitamin A olehkader.

9. Isi kolom pemberian ASI eksklusif

Beri tanda $(\sqrt{ })$ bila pada bulan tersebut bayi masih diberi ASI saja, tanpa makanan dan minuman lain. Bila diberi makanan lain selain ASI, bulan tersebut dan bulan berikutnya diisi dengan tanda (-)(Kementerian Kesehatan RI, 2010)

\section{Metode Penelitian}

Desain yang digunakan dalam penelitian ini adalah desain penelitian preexperimental design. Penelitian ini menggunakan pendekatan One-Group Pretest-Posttest Design.Sampel dalam mengisi KMS di Dusun Sumberwaru, Desa Taman Agung, Kecamatan Cluring. Kabupaten Banyuwangi, Jawa Timur sebanyak 25 orang dengan pengambilan sampel secara simple random sampling.Analisis data menggunakan paired t test.

Data penelitian diambil dengan menggunakan cek list dengan penilaian skor 0-100 untuk mengukur keterampilan kader dalam pengisian KMS. Keterampilan kader sebelum dan sesudah pembelajaran diukur lalu dibandingkan hasil keduanya.

\section{HaSil dan PEMbahaSAN HASIL}

Hasil penelitian dalam penelitian ini dimulai dari karakteristik umum responden yaitu umur yang disajikan dalam tabel berikut ini: 
Tabel 1 Distribusi frekuensi responden berdasarkan usia

\begin{tabular}{cccc}
\hline No & Usia & \multicolumn{2}{c}{ Kelompok } \\
& & n & \% \\
\hline 1 & $17-25$ & 2 & $8 \%$ \\
\hline 2 & $26-35$ & 18 & $72 \%$ \\
\hline 3 & $36-45$ & 5 & $20 \%$ \\
\hline Total & & 25 & 100 \\
\hline
\end{tabular}

Dari tabel 1 sebagian besar responden berusia 26-35 tahun yaitu sebanyak $72 \%$ dan yang paling sedikit berusia $17-25$ tahun yaitu $8 \%$.

Tabel 2 Distribusi frekuensi responden berdasarkan tingkat pendidikan

\begin{tabular}{ccc}
\multicolumn{3}{c}{ berdasarkan tingkat pendidikan } \\
\hline Pendidikan & $(\mathbf{n})$ & $(\boldsymbol{\%})$ \\
\hline SLTA & 22 & 88 \\
Perguruan Tinggi & 3 & 22 \\
\hline Jumlah & 25 & 100 \\
\hline
\end{tabular}

Tabel 4 Perbandingan Skor keterampilan sebelum dan sesudah pembelajaran think, pair and

share

\begin{tabular}{|c|c|c|c|}
\hline \multirow[b]{2}{*}{ Skor } & \multicolumn{2}{|c|}{ Intervensi } & \multirow[b]{2}{*}{ Nilai $\mathbf{p}^{*}$} \\
\hline & $\begin{array}{c}\text { Sebelum } \\
(n=25)\end{array}$ & $\begin{array}{c}\text { Sesudah } \\
(n=25)\end{array}$ & \\
\hline \multicolumn{4}{|l|}{ Keterampilan } \\
\hline Rerata (SD) & $66,8(6,90)$ & $85,2(6,53)$ & $<0,01$ \\
\hline Rentang & 60-80 & 80-100 & \\
\hline
\end{tabular}

Dari tabel 4 tampak bahwa skor keterampilan kader dalam pengisian KMS meningkat dari rerata 66,8 menjadi 85,2 dan dari hasil analisis menunjukkan nilai $\mathrm{p}$ $<0,01$ artinya metode pembelajaran think, pair and share secara significan mampu meningktakan keterampilan kader dalam pengisian KMS.

\section{PEMBAHASAN}

Berdasar hasil penelitian diketahui bahwa rata-rata keterampilan kader sebElum pembelajaran adalah 65,8 hal ini menunjukkan bahwa kader kurang
Tabel 2menunjukkan bahwa sebagian besar responden berpendidikan SLTA/SMA yaitu sebanyak sebanyak $88 \%$. Sedangkan responden yang paling sedikit berpendidikan PT yaitu sebanyak $22 \%$ responden.

Tabel 3 Distribusi frekuensi responden berdasarkan pekerjaan

\begin{tabular}{lcc}
\hline Pekerjaan & (n) & $(\%)$ \\
\hline Bekerja & 5 & 20 \\
Tidak Bekerja/IRT & 20 & 80 \\
& & \\
\hline Jumlah & 25 & 100 \\
\hline
\end{tabular}

Tabel 3 menunjukkan bahwa responden yang bekerja yaitu sebanyak $20 \%$ responden dan tidak bekerja $80 \%$. 
pengisian KMS dilakukan oleh bidan.Kurang aktifnya kader dalam kegiatan posyandu tersebut mempengaruhi keterampilannya, salah satunya mengisi KMS.Keaktifan kader diposyandu dapat mempengaruhi terhadap kemampuandalam mengisi kartu menuju sehat (KMS). Hal ini kemungkinan disebabkan pada kader yang aktif akan mendapat kesempatan yang lebih banyak untuk mengikutipembinaan rutin atau mengikuti kursus,kader juga termotivasi untuk lebih aktif. Dengan demikian kader yang aktif mempunyai kesempatan yang lebih banyak untuk dapat meningkatkan pengetahuan dan memperoleh pengalaman jika dibandingkan dengan kader yang tidak aktif (Nursalam., Agustina, D., 2010)

Faktor yang kedua adalah kegiatan pelatihan yang di dapat kader saat ini belum menggunakan metode yang melibatkan kader berpartisipasi aktif di dalam kegiatan pelatihan tersebut.Seharusnya kegiatan pelatihan dilakukan secara menarik dan melibatkan keaktifan kader sehingga kader benarbenar terampil dikarenakan tidak hanya mendapatkan materi yang siap cerna. Hal ini didukung oleh Syarifuddin\& Hamidah (2007) bahwa para kader kesehatan masyarakat itu tidak bekerja dalam sistem tertutup, tetapi mereka bekerja dan berperan sebagai seorang pelaku kesehatan. Oleh karena itu, mereka harus di bina, di tuntun, serta di dukung oleh pembimbing yg terampil dan berpengalaman serta dengan metode pelatihan yang menarik dan tidak membosankan.

Berdasar hasil penelitian didapatkan bahwa keterampilan kader setelah pembelajaran think,pair and share meningkat yaitu rata-rata 85,2 Hal ini disebabkan oleh karena metode yang digunakan oleh pengajar merupakan metode kooperatif sederhana dengan melalui kegiatan berfikir, berdiskusi dan berbagi suatu keterampilan kepada seluruh kelas, sehingga melalui kegiatan tersebut kader benar-benar menguasai keterampilan. Metode ini juga menciptakan suasana yang menumbuhkan sikap saling berbagi yang positif antar sesama kader, karena terdapat suatu proses berbagi baik kepada pasangan maupun ke seluruh kelas, hal ini dapat mempermudah kader dalam penguasaan suatu keterampilan.

Hal ini didukung oleh Yulianingsih bahwa manfaat pembelajaran ini adalah siswa mampu mengembangkan kemampuan keterampilan yang dimilikinya baik sendiri ataupun berpasangan kemudian keterampilan tersebut diungkapkan ke seluruh kelas. Disamping itu proses pembelajaran menjadi aktif, kader dituntut untuk mengembangkan kemampuan berfikir dan pengajar tidak lagi memberikan pelajaran yang telah jadi dan siap cerna oleh kader.(Yulianingsih et al., 2017)

Hal ini juga sejalan dengan pendapatElhefeni (2011) bahwa metode think,pair and share memudahkan pencapaian tujuan pembelajaran baik konsep,fakta ataupun suatu keterampilan. (Elhefni, 2011)

Hal ini sejalan dengan penelitian Usman (2015) yang meneliti tentang pengaruh metode think, pair and share terhadap keterampilan speaking mahasiswa IAIN. (Abdurrahman Usman, 2015)

Sahrin dan Riki (2013) juga mengungkapkan hasil penelitian yang sama, penelitian mereka menganalisis pengaruh metode think, pair and share dalam meningkatkan keterampilan siswa 
dalam reading. Dalam penelitian tersebut dari 23 siswa intervensi menggunakanmetode think, pair and share. Ddari hasil penelitian tersebut nilai rata-rata siswa meningkat dari 53,73 menjadi 69,13.

Karakteristik seorang pembelajar juga mempengaruhi keterampilan yang didapat dari suatu proses pembelajaran. Seperti usia, semakin dewasa usia semakin baik pengetahuannya sehingga semakin terampil pula kader tersebut dalam kegiatan posyandu, dari tabel diketahui bahwa rata-rata usia responden adalah 2635 tahun yang menunjukkan bahwa usia responden adalah usia yang cukup matang. Sebab menurut Notoadmodjo (2014) semakin cukup umur tingkat kematangan dan kekuatan seseorang akan lebih matang dalam berfikir dan melakukan sesuatu. Karakteristik lainnya yang mendukung adalah lulusan pendidikan. Dari gambar tingkat pendidikan reponden lulus dari tingkat SLTA. Hal ini yang mendasari kemampuan responden untuk mengingat kembali, menghubungkan dan menjelaskan informasi menjadi mudah. Karena semakin tinggi pendidikannya akan semakin baik keterampilannya. Sebab menurut Notoadmodjo (2014) bahwa pendidikan dapat mempengaruhi seseorang termasuk juga perilaku akan pola hidup terutama dalam motivasi berperan serta dalam pembangunan kesehatan. Semakin tinggi tingkat pendidikan maka semakin bertambah pula kecakapan keterampilannya baik secara intelektual dan emosional.

Dari pembahasan diatas diketahui bahwa banyak faktor yang mempengaruhi keterampilan kader dalam menjalakan tugasnya di posyandu. Dalam hal ini perlu dicermati faktor-faktor tersebut dalam memberikan pendidikan maupun pelatihan kepada kader mulai dari karakteristik peserta didik, metode yang digunakan dalam penyampaian serta proses evaluasi.

\section{KESIMPULAN}

Metode Think, Pair and share mampu meningkatkan keterampilan kader dalam mengisi KMS dengan skor rata-rata 66,8 menjadi 85,2. Banyak faktor lain yang memengaruhi keterampilan kader yang tidak diukur dalam penelitian ini, diharapkan penelitian berikutnya menggunakan kelompok kontrol sebagai pembanding dalam intervensi suatu metode pembelajaran.

\section{Daftar Pustaka}

Abdurrahman Usman. (2015). Using the Think-Pair-Share Strategy to Improve Students Speaking Ability at Stain Ternate. Journal of Education and Practice, 6(10), 37-46. https://doi.org/10.1016/S03063623(98)00186-4

Abidin, C., Amin, S. M., \& Sulaiman, R. (2018). The Effect of Think-PairShare Learning with Contextual Approach on Junior High School Students , Mathematics Problem Solving Ability, 157(Miseic), 31-34.

Bugis, R., \& Buru, U. I. (2018). Think Pair Share Technique To Improve Students ' Reading, (November 2013).

Elhefni. (2011). Model Pembelajaran Kooperatif Tipe Think Pair Share Dan Hasil Belajar Di Sekolah. Ta'Dib, XVI(2), 303-317.

Endo Dardjito, Colti Sistiarani, S. N. (2014). Deteksi Pertumbuhan Dan Perkembangan Balita Melalui Penggunaan Buku Kia, Volume 6, 166-176.

Kementerian Kesehatan RI. (2010). PedomanPenggunaan-KMS_SK-Menkes.pdf.

Marhaeni, P., Putra, A., \& Jaya, N. A. (2013). The Effect of Think Pair Share Teaching Strategy To Students' SelfConfidence and Speaking Competency of the Second Grade Students of Smpn 
6 Singaraja. E-Journal Program Pascasarjana Universitas Pendidikan Ganesha Program Studi Pendidikan Bahasa Inggris, 1(01).

Nursalam., Agustina, D., A. N. K. A. (2010). Training Pengisian Kartu Menuju Sehat (Kms) Merubah Perilaku Kader Posyandu Balita. Jurnal Ners, 5(1), 70-78.

Raba, A. A. A. (2017). The Influence of Think-Pair-Share (TPS) on Improving Students' Oral Communication Skills in EFL Classrooms. Creative Education, $\quad$ 08(01), 12-23. https://doi.org/10.4236/ce.2017.81002 Yulianingsih, L., Ledlow, S., Excellence, T., Usman, A., Ledlow, S., Nuary, M. G., ... Tomaswick, L. (2017). The Effect of (Think-Pair-Share) Strategy on the Achievement of Third Grade Student in Sciences in the Educational District of Irbid. Journal of Education and Practice, 3(July), 1-2. https://doi.org/10.4271/2010-01-2319 